\title{
An Archaeological Survey of Proposed Areas for Alternate Roadways at Olmos Dam, San Antonio, Texas
}

David Brown

Follow this and additional works at: https://scholarworks.sfasu.edu/ita

Part of the American Material Culture Commons, Archaeological Anthropology Commons, Environmental Studies Commons, Other American Studies Commons, Other Arts and Humanities Commons, Other History of Art, Architecture, and Archaeology Commons, and the United States History Commons

Tell us how this article helped you.

This Article is brought to you for free and open access by the Center for Regional Heritage Research at SFA ScholarWorks. It has been accepted for inclusion in Index of Texas Archaeology: Open Access Gray Literature from the Lone Star State by an authorized editor of SFA ScholarWorks. For more information, please contact cdsscholarworks@sfasu.edu. 


\section{An Archaeological Survey of Proposed Areas for Alternate Roadways at Olmos Dam, San Antonio, Texas}

\section{Creative Commons License}

\section{(c) (1) (8)}

This work is licensed under a Creative Commons Attribution-NonCommercial 4.0 International License 


\section{AN ARCHAEOLOGICAL SURVEY OF PROPOSED AREAS \\ FOR ALTERNATE ROADWAYS AT OLMOS DAM,}

SAN ANTONIO, TEXAS

David Brown

Center for Archaeological Research The University of Texas at San Antonio Archaeological Survey Report, No. 37 
AN ARCHAEOLOGICAL SURVEY OF PROPOSED AREAS FOR ALTERNATE

ROADWAYS AT OLMOS DAM, SAN ANTONIO, TEXAS

David Brown

Center for Archaeological Research

The University of Texas at San Antonio

Archaeological Survey Report, No. 37

1977 
TABLE OF CONTENTS

$\begin{array}{lc} & \text { Page } \\ \text { INTRODUCTION } & 1 \\ \text { ALTERNATE ROUTE IV-B } & 1 \\ \text { Previous Archaeological Research } & 1 \\ \text { Survey Results } & 3 \\ \text { Recommendations } & 3 \\ \text { ALTERNATE ROUTE VI } & 5 \\ \text { Previous Archaeological Research } & 5 \\ \text { Survey Results } & 5 \\ \text { Recommendations } & 7 \\ \text { CONCLUSIONS } & 7 \\ \text { ACKNOWLEDMENTS } & \text { LIST OF FIGURES } \\ \text { REFERENCES CITED } & 8\end{array}$




\section{INTRODUCTION}

On June 16, 1977, an archaeologist from the Center for Archaeological Research, The University of Texas at San Antonio, conducted a surface survey in the area of 0lmos Dam. The areas surveyed include the 250-foot right-of-way just to the south of the dam, and also an area extending roughly 500 feet north of the dam (Fig. 1). These are two of several areas considered for an alternate vehicle road to be used during planned modifications to olmos Dam. The proposed routes under study which were surveyed are listed as road alternatives IV-B and VI as shown on plans supplied by W. E. Simpson Co., Inc., Consulting Engineers, dated May 31, 1977.

The survey was conducted under contract between the Center for Archaeological Research and the City of San Antonio Public Works Department. Fieldwork was done by Mr. David Brown, under the direction of Dr. Thomas R. Hester, Center Director and Mr. Jack D. Eaton, Research Associate of the Center.

The two areas surveyed were inspected for surface indications of archaeological resources, and, in addition, subsurface shovel testing was done in selected places to aid in evaluations. All archaeological materials collected in the survey are now in the permanent collection maintained by the Center. This report is based in part upon the preliminary study submitted to the City Planning Commission on June 21, 1977.

\section{ALTERNATE ROUTE IV-B}

\section{Previous Archaeological Research}

For years local collectors have known the Olmos Basin to be an area rich in archaeological materials. Local archaeologists have remarked on the quality of lithic workmanship at sites south of the dam near where proposed route IV-B would cross (Woolford 1935). Several sherds of Southwestern pottery, including Reserve Black-on-White, Tularosa Black-on-White and Los Lunas Smudged, were found on the surface in this area before the dam was built (Orchard and Campbel1 1960). Construction of the Olmos Dam and subsequent activities in the basin have destroyed a large part of this cultural resource.

The area south of the dam in the 0lmos Basin was originally recorded as site 41 BX 24. Excavations in 1974 by the Texas. Highway Department found that this site did not extend onto the right-of-way for the Northwest Expressway (Luke 1974:7-10). In 1974 an archaeological survey conducted by Anne Fox of the Center for Archaeological Research (Fox 1975) subdivided this large site into several smaller concentrations which were assigned individual numbers. This entire area was subsequently designated a State Archaeological Landmark.

The map included in the report of the 1975 survey is not drawn to scale and the sites indicated on this map mistakenly appear to extend onto the city owned right-of-way, although the survey did not include the 250-foot strip in front of the dam. One of the more significant sites recorded in the survey, 41 BX 291, does extend to the Incarnate Word property line as confirmed by excavations by Paul and Susanna Katz in the summer of 1976 (Susanna Katz, personal communication). 
Figure 1. Olmos Dam. a, View of area below the dam, looking east. Road alternate route IV-B. b, View of area above the dam, looking east. Road alternate Route VI. 

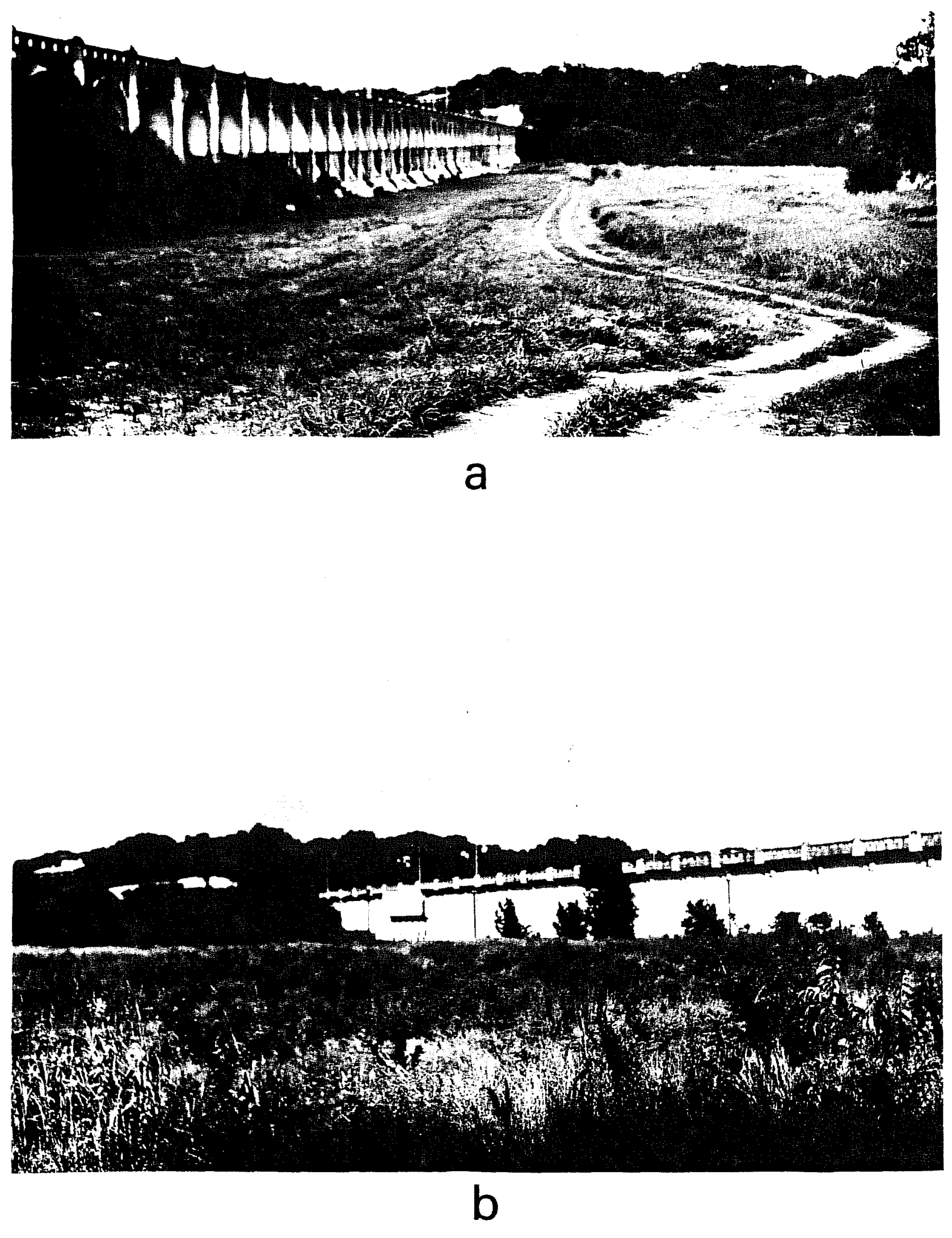
Survey Results

Investigation of the surface of the right-of-way to the south of the dam yielded indications of light prehistoric occupations. Burned rocks and a number of chert flakes were seen on the surface of the access road which parallels the dam in the northern half of the right-of-way. Two bifaces were collected from this road surface midway between the expressway and olmos Creek. One is a thin ovate biface $6.6 \mathrm{~cm}$ in length and $4.7 \mathrm{~cm}$ at its widest point. Numerous step fractures on one face indicate that it was orfginally intended to be further thinned, and a macro-wear analysis shows that it may have functioned as a knife (Andrea Gerstle, personal communication). Also found on the road was a thin biface tip with unifacial wear on both edges and a slightly blunted tip.

Dense long-stem grass cover in the southern portion of the right-of-way made reconnaissance especially difficult. Despite the grass, a few flakes and burned rocks were seen on the surface in the area of the proposed roadway. In order to facilitate inspection of this area, five shovel tests (非 - 非) were located along the course of the proposed alternate route. The approximate locations of these tests are shown on the plan of the surveyed area (Fig. 2). Two interior flakes were found in test $\# 1$, a cortex flake in test \#2, and an interior flake in test $\$ 4$. Burned rocks were noted in all but test $\$ 4$, and small pieces of charcoal were present in all the tests. Test \#5 also contained a non-utilized chert nodule. All of the cultural material was found above a layer of gravel in the soil at a depth of approximately $15 \mathrm{~cm}$, a circumstance also reported by Highway Department archaeologists (Luke 1974:7).

On the east bank of the Olmos Creek, burned rocks and a few chert flakes were noted on the surface but such indications of archaeological resources were sparse. No subsurface tests were deemed necessary. Inspection of the cliff area on this side of the creek showed no traces of either prehistoric chert quarries or historic lime kilns. A sherd of crockery from this side and a few pieces of colored square bottle glass from the other bank are too nondescript to be identified as to specific time period.

Recommendations

Artifacts found in the survey of the proposed roadway alternative are not necessarily considered to indicate a new archaeological site in the area. Instead, these remains must certainly relate to the repeated use of the entire basin area by prehistoric peoples, a fact somewhat disguised by the separation of the old site 41 BX 24 into discrete concentrations with separate numbers.

It seems possible that a small and widely scattered deposit of artifacts relating to this general occupation will be destroyed by construction of the proposed roadway. Although the direct impact of the roadway is likely to be slight, there is some concern for the indirect effects which the new road may have on the important archaeological resources present at site 41 BX 291, located directly south of the fence line of the Incarnate Word College property. As a State Archaeological Landmark this site deserves complete protection from destruction as a result of activities related to construction of the road. 
This page has been

redacted because it

contains restricted

information. 
Increased access brought about by the new road is likely to increase vandalism and unauthorized collecting activities, already a problem at the site (Susanna Katz, personal communication). A change in water runoff patterns could conceivably cause destruction of parts of the site through soil erosion (cf. Katz and Katz 1977). Minimum protective measures, such as a tall hurricane fence with accompanying hedge, and a concrete runoff channel on the southern shoulder of the road, are recommended. In addition, due to the nearness of site $41 \mathrm{BX} 291$ to the fence line, we recommend intensive testing of this fringe area before the construction of the suggested protective measures; such testing will help to mitigate expected damage. Given such protective measures, the proposed route IV-B can be constructed with minimal damage to the archaeological resources in the area.

\section{ALTERNATE ROUTE VI}

\section{Previous Archaeological Research}

The proposed route of plan VI (Fig. 2) crosses two long-known archaeological sites, one of prehistoric and the other, historic significance. North of the Olmos Dam, between the west bank of the Olmos Creek and the bluff which marks the edge of the floodplain, is the site known as $41 \mathrm{BX} 1$. During the autumn and winter of 1921-1922, C. D. Orchard and J. H. McLellan collected 11 Paleo-Indian projectile points at this site (Orchard and Campbel1 1954). More sherds of the Southwestern pottery mentioned above were also found in this area (Orchard and Campbell 1960), as well as numerous sherds of local pottery types (Fawcett 1972:37). As on the other side of the dam, the greater portion of this very important site was obliterated by dam construction and subsequent activities. Test excavations by the Texas Highway Department prior to the construction of the Northwest Expressway found indications of prehistoric occupation but no Paleo-Indian material. Luke (1974) concluded that the highway right-of-way did not go through the main area of the site, and that the site had been much disturbed by recent human activities.

In the 1975 survey of portions of the basin, Anne Fox (1975) reported that Worth's Spring, used as an encampment after the Mexican War by troops under the command of General W. J. Worth, is supposed to be located on the north side of the dam at its eastern end near where the proposed roadway of plan VI would rejoin Olmos Drive. This reported site was not visited at the time of that survey and it was not given an official site number.

\section{Survey Results}

Surface inspection of the area of proposed roadway VI found very little indication of prehistoric occupation. Only a few flakes were seen on the surface in the area which had apparently been the golf driving range at one time. A few burned rocks in this area and farther toward the banks of olmos Creek may signal prehistoric occupation, or they may simply indicate that at various times vegetation in the flood basin has been cleared by fire. Three shovel tests (非, 非, 非) found no culturally related material and a generally shallow soil profile (see Fig. 2 for location). 


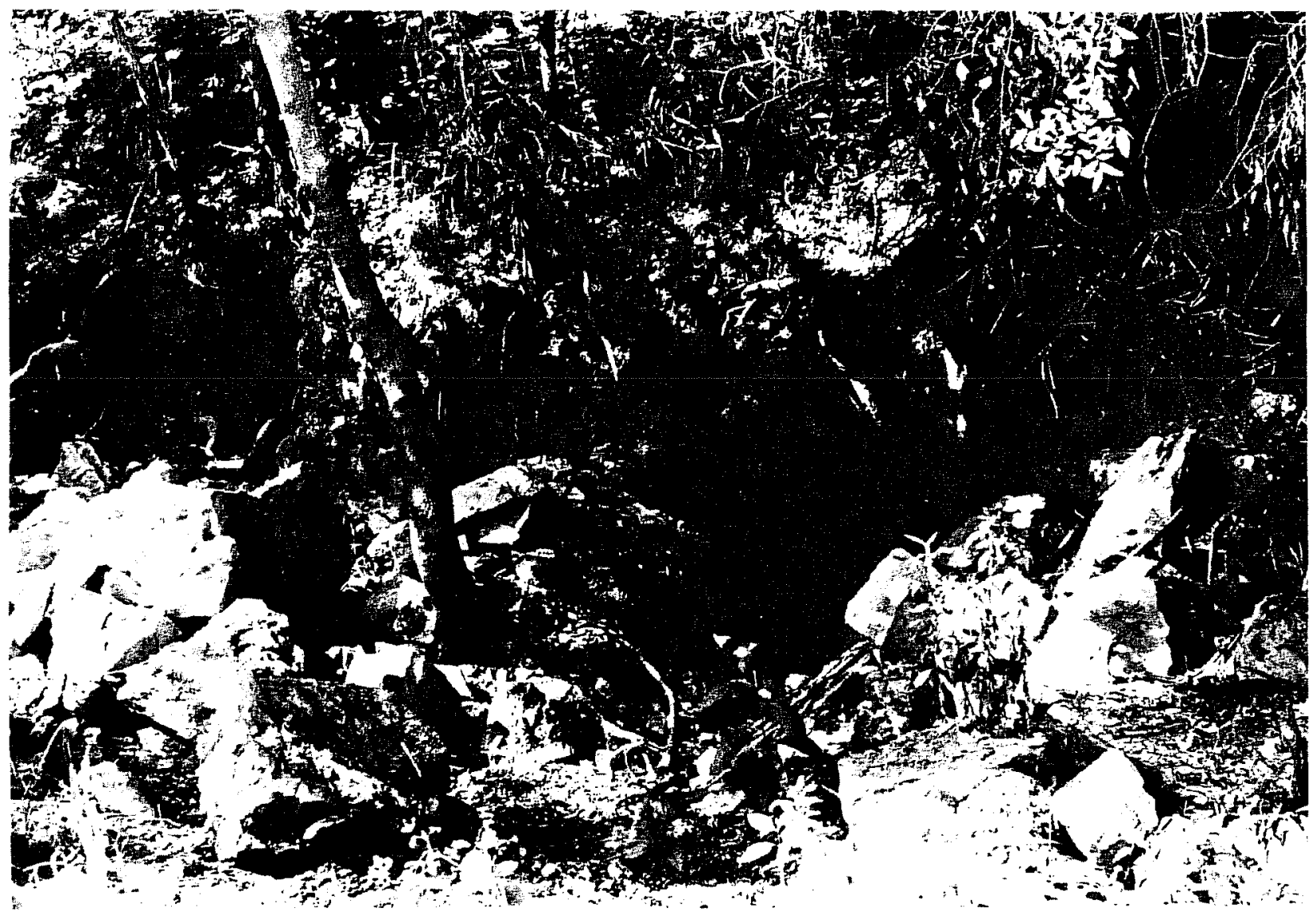

Figure 3. Worth's Spring. The spring is located near the northeast end of Olmos Dam. 
Several sherds of historic earthenware and fragments of glass were collected during the survey, but they were not distinct enough to identify as belonging to any specific perjod. A buried trash dump was located just north of the proposed roadway, but there was no indication that any of the material was pre20th century. At the northeastern end of the dam, a spring was located where the 1975 Center survey indicated it should be. There were no immediate indications of a military encampment, but recent litter thrown from the dam and garbage left by recent visitors to the spring made surface reconnaissance difficult (Fig. 3).

Two areas on the northern side of the dam were not visited during this survey. It was not clear whether a small strip of land between Devine Road and the expressway was private property; and, a small peninsula of land between the 01mos Creek and a small branch which joins it just above the dam was not easily accessible in the time available.

\section{Recommendations}

Although small pockets of an important site, 41 BX 1 , may still exist near the northwestern end of the dam, it is likely that construction activities in the area from the 01mos Dam to the expressway have destroyed the greater part of the cultural deposits. Apparently no further work is possible at this site, which may have once been one of the most significant in the San Antonio area.

Although no historic structures are documented in the right-of-way of the proposed roadway, Worth's Spring may be endangered by construction. It was difficult to precisely locate the spring on a map; however, it appears to lie within the right-of-way but not directly under the proposed roadway. Even if the spring were not to be directly destroyed by construction of the road, it is highly possible that any signs that remain of the original military encampment could lie well within the area to be modified by construction. While it is not certain from surface reconnaissance that anything remains of this encampment, there appears to be sufficient evidence to warrant further research. Specifically, I recommend a four-phase program of research and subsequent protection which I believe should be completed before this roadway proposal is acceptable:

1) Verification of this area as the actual location of Worth's Spring and such historical research as is necessary to document activities connected with the spring.

2) Exact location of the spring with respect to the right-of-way and an assessment of the impact of construction upon the spring and associated archaeological resources. This should include archaeological testing in the surrounding areas and excavation where it is deemed necessary.

3) Appropriate measures for protection of the spring from destruction by construction or related activities, and protection from future damage by vandalism.

4) Maintenance of public access to Worth's Spring. While we recognize that it conflicts somewhat with the desire to protect the spring from vandalism, a historical resource such as Worth's Spring belongs to the 
public. Therefore, free public access to the spring should be maintained and permanent markers should be placed at the site displaying information found through historical and archaeological research.

\section{CONCLUSIONS}

In the cases of both proposed roadways, there are potential damaging effects to important archaeological and historical resources. With proper protective measures, it is probable that either plan can be carried out with no change in engineering design. In both cases, however, these protective measures may add substantially to the expense of construction and we suggest that these estimates be reviewed before further consideration of these proposals.

A glance at the other proposals under consideration shows that with the possible exception of the improvement of Devine Road, each route is likely to cause considerable damage to significant archaeological sites, and can therefore be expected to incur increased costs from an archaeological standpoint. We therefore recommend that before any of the proposals are implemented, the additional cost in terms of archaeological protective measures be estimated through consultation with a professional archaeologist.

\section{ACKNOWLEDGMENTS}

Several people deserve credtt for their contributions to this report. The author is grateful to Jack Eaton, Elizabeth Branch, and Dr. Thomas R. Hester for editing the report, and to Andrea Gerstle and Anne Fox for helping with artifact identification. Special thanks go to Paul and Susanna Katz, without whose assistance this report would have been considerably more difficult to complete.

\section{REFERENCES CITED}

Fawcett, W. B., Jr.

1972 The Prehistory of Bexar County: A Study of Previous Work in South Central Texas. Lower Plains Archaeological Society Bulletin 2:23-44.

Fox, A. A. (with an appendix by T. R. Hester)

1975 An Archaeological Assessment of the Southern Portion of the olmos Basin, Bexar County, Texas. Center for Archaeological Research, The University of Texas at San Antonio, Archaeological survey Report 9.

Katz, S. and P. Katz

1977 Priority Ranking of Alternative Plains for the Olmos Dam Road, in Terms of Prehistoric Resources. Excerpt from a letter to the Texas Historical Commission. 
Luke, C.

1974 Archeological Investigation Along the Route of U.S. 281, from Mulberry Avenue to Tuxedo Avenue in San Antonio. Texas Highway Department manuscript. Austin.

Orchard, C. D. and T. N. Campbel1

1954 Evidence of Early Man from the Vicnity of San Antonio, Texas. Texas Journal of Science 6(4):454-465.

1960 Southwestern Pottery from Sites in the Vicinity of San Antonio, Texas. Texas Archeology 4(2):7-8.

Woolford, S. W.

1935 Types of Archaeological Sites in Bexar County, Texas. Archaeological Bulletin 4, Witte Museum, San Antonio. 
